\title{
Renal Papillary Adenoma
}

National Cancer Institute

\section{Source}

National Cancer Institute. Renal Papillary Adenoma. NCI Thesaurus. Code C3687.

A low grade, unencapsulated neoplasm with papillary, tubular, or tubulopapillary

architecture, less than $15 \mathrm{~mm}$ in size. 